ESTUDOS REEP

\title{
Professores e Educação Ambiental: implicações para o currículo
}

Mara Rejane Vieira Osório

\section{Resumo}

Este texto é parte de uma pesquisa qualitativa que teve como instrumentos de coleta de dados questionário, entrevistas e observações. O foco teórico seguiu contribuições dos estudos pós-estruturalistas que, na área da educação, vêm problematizando a questão do currículo e suas implicações produtivas. Discute a relação entre os professores e os discursos sobre Educação Ambiental movimentados pela Secretaria Municipal de Qualidade Ambiental (SQA) de Pelotas, Rio Grande do Sul (RS). Mostra que os discursos e as estratégias sobre a Educação Ambiental que essa secretaria movimentou acabaram influenciando os modos de pensar e agir dos professores em termos de Educação Ambiental. Defende que essa relação, entre professores e a SQA, ajudou a reforçar no espaço escolar um tipo de currículo de Educação Ambiental chamado currículo turístico.

Palavras-chave: Educação Ambiental; professores; discursos. 


\section{Abstract}

\section{Teachers and Environmental Education: curriculum implications}

This text is part of a qualitative research that used as data collection instruments questionnaires, interviews and observation. The theoretical focus followed contributions of the poststructuralist studies that, in educational area, use to problematize the curriculum and its productive implications. The study discusses the relation among teachers and the Environmental Education discourses taken by the Environmental Quality Municipal Secretary of Pelotas, Rio Grande do Sul State. It shows that the discourses and strategies used by this Secretariat influenced the teachers' way of thinking and acting. It defends that the relation among teachers and the Environmental Quality Secretariat reinforced a kind of environmental education curriculum known as tourism curriculum.

Keywords: Environmental Education; teachers; discourses.

\section{Introdução}

O artigo $^{1}$ enfoca a relação dos professores com a Educação Ambiental (EA). Sabe-se que a Educação Ambiental surgiu, ou ganhou centralidade, a partir dos anos de 1990, dentro das discussões do movimento ambientalista, com a finalidade de desenvolver mecanismos educativos capazes de desencadear outras representações e significados sobre as relações entre os seres humanos e a natureza. O entendimento era de que o uso dos elementos naturais de forma intensa, desordenada e depredatória impediria o desenvolvimento econômico dos países e afetaria a qualidade de vida das populações, colocando em risco a própria sobrevivência da espécie humana. O objetivo conferido à Educação Ambiental foi o de trazer os saberes ambientais para a escola, diante da concepção de que a escolarização tem papel fundamental no processo de produção de novas condutas constituídas de valores mais respeitosos, cuidadosos e críticos para com a natureza. Os anos 2000 foram muito influenciados pela Lei $\mathrm{n}^{\circ}$ 9.795/1999 (que instituiu a Educação Ambiental), sendo o período mais efervescente da luta pelo fortalecimento da EA nas diferentes esferas da vida social. Nesse movimento, várias vozes (ambientalistas, órgãos governamentais ambientais, empresas, mídia e estudos) pressionavam intensamente as escolas e seus professores para que assumissem a responsabilidade para com o desenvolvimento de práticas de Educação Ambiental. Alguns professores, interpelados por essas manifestações,
1 Este texto é parte de um estudo de mestrado, realizado entre 2002 e 2004, no qual tratei dos discursos e das práticas pedagógicas em Educação Ambiental de 11 professores de 5 escolas municipais de Pelotas/RS 
buscavam responder aos apelos dos discursos da Educação Ambiental, mas não encontravam respostas em seu campo de ação: a educação.

Tendo em vista essa demanda que se apresentou para as escolas, o objetivo principal deste texto é colocar em debate alguns aspectos que constituíram essa relação dos professores de escolas municipais com a Educação Ambiental, no período entre 2002 e 2004, na cidade de Pelotas, Rio Grande do Sul. Meu foco está direcionado a destacar a Educação Ambiental como um instrumento de poder produzido e criado para modificar as condutas escolares e transformá-las de acordo com determinadas expectativas e esperanças. Quero mostrar que os discursos da Educação Ambiental como prática, como instrumento no qual determinadas racionalidades transitam, incutem significados, intenções e ações que interpelam as condutas e lhes preparam para a ação e que esses discursos e as condições que eles impõem não são simplesmente naturais para os currículos escolares - criam um quadro ou sistema de razão por meio do qual a Educação Ambiental passa a ser desejada, compreendida, pensada, desenvolvida, subsidiada e mantida dentro do quadro produzido e limitado.

O artigo está organizado da seguinte forma: primeiro, faço uma breve apresentação dos fundamentos teóricos que me ajudaram a pensar e articular os argumentos sobre Educação Ambiental e os discursos dos professores. Na sequência, debato como os professores foram interpelados pelos discursos movimentados pela Secretaria Municipal de Qualidade Ambiental (SQA) e chamo a atenção para a produtividade dessa relação nas práticas pedagógicas de Educação Ambiental que foram implementadas no contexto das escolas.

\section{Ferramentas teóricas}

Para alcançar o fim a que me propus, apoiei-me em contribuições dos estudos pós-estruturalistas, de cunho foucaultiano, que, nos últimos anos, vêm problematizando a questão do currículo e suas implicações produtivas. Trabalhei, especialmente, com três conceitos para compreender o que acontecia com a Educação Ambiental nos currículos escolares: discurso, sujeito e poder.

O conceito de discurso como "o conjunto de enunciados que se apoia em um mesmo sistema de formação discursiva" (Foucault, 2004, p. 121) contribui em dois aspectos: primeiro, é tratado como produto de relações de poder-saber que definem as regras, as normas, os significados e as representações que os discursos podem mobilizar ou não; segundo, pelos

${ }^{2}$ Prática discursiva: "é um conjunto de regras anônimas, históricas, sempre determinadas no tempo e no espaço que definiram, em uma dada época e para uma determinada área social, econômica, geográfica ou linguística, as condições de exercício da função enunciativa" (Foucault, 2004, p. 133). seus efeitos produtivos, ou seja, os discursos como práticas ${ }^{2}$ que fabricam, sistematicamente, significados de sujeitos, identidades e representações com as quais passamos a agir social e politicamente. É necessário salientar que os discursos obedecem a certas regras, regularidades e processos de dispersão que lhes são muito próprios; assim, não se resumem a frases, palavras ou signos que designam ou nomeiam as coisas do mundo. Os discursos fazem muito mais do que nomear algo: eles instituem, produzem 
seus objetos a partir de relações de poder, das tecnologias, das táticas e estratégias que colocam em ação. Como diz Larrosa (2002, p. 21),

as palavras produzem sentidos, criam realidades e, às vezes, funcionam como potentes mecanismos de subjetivação. [...] As palavras determinam nosso pensamento porque não pensamos com o pensamento, mas com palavras, não pensamos a partir de uma generalidade ou inteligência, mas a partir de nossas palavras.

Portanto, é mediante os discursos que os significados são constituídos e acionados; que as verdades circulam e penetram nos corpos, na alma, nos gestos e nos comportamentos; que novos papéis e novas subjetividades, novas formas de disciplina, novas formas de avaliação e novos sistemas éticos são introduzidos (Ball, 2002).

Penso que a linguagem, como discurso, é uma chave importante no processo de governo da conduta dos professores e dos alunos, porque ela habilita o sujeito a viver tipos de vida específicos e particulares (Rose, 1996). Os seres humanos são seres da linguagem, não no sentido de que a possuem como uma coisa, mas no sentido de que "todo o humano tem a ver com palavra, se dá em palavra, está tecido de palavras, que o modo de viver próprio desse vivente, que é homem, se dá na palavra com a palavra" (Larrosa, 2002). Assim, o discurso é uma prática social ativa, produtiva e criativa; é uma ação ou uma estratégia que trabalha para, ou sobre, alguma coisa: um desejo, uma necessidade ou uma intenção. O discurso é um elemento estratégico para as relações de poder; é um meio ou um artefato por onde o poder circula e produz. Como já argumentava Foucault (2004, p. 234), em A arqueologia do saber, "falar é dizer alguma coisa" que não supõe apenas "ideias novas, um pouco de invenção e criatividade, uma mentalidade diferente, mas transformações em uma prática".

Entender os discursos nessa perspectiva levou-me a perceber os sujeitos de modo diferente daquele produzido, construído pelo Iluminismo: sujeito centrado, racional, livre, soberano, autorregulado. Passei a compreender o sujeito como um ser que produz, produz-se e é produzido por relações de poder-saber em diferentes sociedades com seus contextos, discursos e necessidades. Assim, o sujeito não é uma essência, ele é derivado dos discursos, das tecnologias de poder, das práticas sociais e discursivas. Esse modo de ver os sujeitos e os discursos mostrou-me que as práticas pedagógicas de Educação Ambiental desenvolvidas pelos professores entrevistados foram marcadas por discursos advindos de múltiplos lugares (do movimento ambientalista, das ciências, das políticas públicas da área do meio ambiente e da área da educação - como os Temas Transversais -, da mídia, de leis e normas ambientais, etc.). Mas, nesse movimento, chamo a atenção para o impacto dos discursos que emergiram de políticas públicas do governo municipal local na área de meio ambiente. Esses discursos, durante o tempo que desenvolvi o estudo, funcionaram como subsídios básicos para a produção, a organização e a manutenção de um tipo especial de Educação Ambiental escolar. 
A noção de poder, nessa perspectiva de estudo, desloca-se daquela ideia de um poder que se realiza a partir de formas de violência sobre os indivíduos, um poder que distorce, reprime, mistifica e domina e que está localizado num lugar específico, como o Estado, por exemplo. Como mostra Roberto Machado (1988, p. 14), no texto de introdução do livro Microfísica do poder,

o poder não é algo que se detém como uma coisa, como uma propriedade, que se possui ou não. Não existem de um lado os que têm o poder e de outro aqueles que se encontram dele alijados. Rigorosamente falando, o poder não existe: existem, sim, práticas ou relações de poder. O que significa dizer que o poder é algo que se exerce, que se efetua, que funciona. E que funciona como uma maquinaria, como uma maquinaria social que não está situada em lugar privilegiado ou exclusivo, mas se dissemina por toda a estrutura social.

Foucault (1988) chamou a atenção para o sentido positivo do poder e mostrou que o que faz com que um poder se mantenha vivo não é uma relação de controle-repressão, mas uma relação de controle-estimulação, ele diz: "Fique nu ... Mas seja magro, bonito, bronzeado!". É com essa possibilidade de estimular seres humanos a serem melhores do que eram antes (mais bonitos, mais conscientes, mais políticos, mais felizes, mais qualificados...) que se "produz efeitos positivos ao nível do desejo e do saber" e não a repressão, a censura, o impedimento e o recalcamento. É assim, nesse nível de poder, que as práticas de governo e poder podem acontecer: não fora dos sujeitos ou acima deles, mas, ao contrário, com eles, estimulando-os a terem vontades, desejos e necessidades. É nesse sentido que o poder promove o governo das condutas e dos comportamentos humanos; é ação de uns sobre os outros visando a determinados objetivos ou resultados; é também, nesse aspecto, que o poder é produtivo ou que "possui uma eficácia produtiva, uma riqueza estratégica, uma positividade. E é, [...] nessa condição, que se explica o fato de que tem como alvo o corpo humano, não para supliciá-lo, mutilá-lo, mas para aprimorá-lo, adestrá-lo" (Foucault, 1988, p. 16).

Seguindo essa perspectiva, preciso ainda dizer que trabalho neste texto com uma ideia particular de currículo: um conjunto de todas as experiências de conhecimento que a escola proporciona aos estudantes (Silva, 1996), seja em seu caráter escrito de conteúdos, de disciplinas, dos valores e conceitos, seja nas experiências vividas na prática cotidiana das salas de aula ou nos corredores das escolas. O currículo é, antes de tudo, uma fabricação social caracterizada por um processo de concorrência entre diferentes interesses que objetivam produzir conhecimentos sociais e válidos. Tudo o que acontece na escola, portanto, envolve meios e métodos de produzir e "construir significados, reforçar e conformar interesses sociais, formas de poder, de experiência, que têm sempre um significado cultural e político" (Santomé, 1995, p. 166). O currículo como instância política é um local de conflito e disputa para se definirem aspectos considerados mais ou menos importantes, certos ou errados, bons ou ruins, normais ou anormais, para a educação dos estudantes. Seguindo essa ideia, penso que os currículos de Educação Ambiental são 
espaços de ações, estratégias, táticas e instrumentos que buscam tornar real, verdadeiro e fixo um conjunto de significados específicos para o ambiental. Considero que os currículos das escolas não têm nada de neutro ou natural, ao contrário, eles sempre querem alguma coisa (Corazza, 2001), são pautados por desejos e interesses e são espaços produtivos. Produtivos no sentido de que criam significados, representações, identidades, relações, comportamentos, conceitos e práticas que podem se tornar verdades incontestáveis, fechadas e fixadas.

Em resumo, minha intenção, seguindo essas sugestões, é mostrar que a Educação Ambiental não existe, no sentido de ser única, plena, neutra ou natural, ela é, ou torna-se, aquilo que fazemos dela a partir das diferentes práticas e dentro de relações que conjugam poder-saber. Ou seja, quero destacar que a Educação Ambiental é parte dos planos ou, mais especificamente, de racionalidades de poder que são organizadas, planejadas, pensadas, definidas e materializadas nos currículos escolares, com o objetivo de influenciar e transformar determinadas condutas humanas.

Esclarecidos os objetivos do texto e a base teórica que o atravessa, saliento que esta pesquisa sobre currículos de Educação Ambiental contou com a contribuição e participação de 11 professores que se dedicavam ativamente à Educação Ambiental em 5 escolas de regiões diferentes em Pelotas: 5 coordenadores de projetos de Educação Ambiental e 6 professores sugeridos por eles como sendo aqueles que mais se envolviam ou eram sensíveis a colaborar em atividades de Educação Ambiental quando convidados. Os instrumentos utilizados para coleta de dados foram, prioritariamente, a entrevista e, como complemento, a análise de textos (projetos e materiais usados pelos professores). Quanto ao estudo dos dados, segui uma análise descritiva dos discursos e procurei expor as relações e os modos de fazer que foram colocados em ação por esses próprios discursos, como preconizado por Fischer (1995, 2001). Quis mostrar que os discursos acionados nas escolas têm efeitos produtivos no âmbito escolar, produziram e instituíram verdades sobre práticas pedagógicas de Educação Ambiental, sobre o que é a temática ambiental e sobre a definição dos objetivos da Educação Ambiental. Não procurei uma essência, uma origem, uma natureza transcendental dos discursos sobre Educação Ambiental, entendi-os como uma verdade gerada mediante relações de poder, necessidades, lutas, disputas que aconteceram em certo momento histórico e social. Também, não quis fazer julgamentos de valor acerca desses discursos e definir se um é mais ou menos importante, real ou melhor do que o outro, quis mostrar que eles existiam e vinham produzindo significados, representações que se colocavam como verdades nas escolas.

\section{Educação Ambiental, professores e governo local: a produtividade da relação}

É necessário olhar com mais profundidade para segmentos sociais que tomam os currículos escolares como veículo de divulgação de desejos 
particulares - essa política de ação no espaço escolar contribui para que a escola seja como é. Parece que os estudos sobre o currículo pouco levaram em consideração os discursos governamentais ambientais e sua interferência nos modos como os professores produzem práticas pedagógicas. Enquanto sujeitos plurais, os professores estão envolvidos em uma miríade de discursos, teorias, experiências, práticas, tensões, sugestões, modos de ser e pensar que advém de diferentes espaços, não se restringindo, apenas, aos conhecimentos que são mobilizados no espaço da escola e da área da educação - formação, teorias pedagógicas, organização da escola, áreas de conhecimento, etc. Esse conjunto de conhecimentos, com os quais os docentes entram em contato, mistura-se, conjuga-se com outros discursos e práticas e marca a produção de suas práticas pedagógicas.

No caso das experiências educativas de Educação Ambiental nas escolas estudadas, houve uma forte relação dos professores com o órgão governamental local, a SQA. Essa relação, pela forma como se estabeleceu, parece ter influenciado os discursos dos professores e suas práticas. Durante a pesquisa, todos os professores descreveram a ampliação de seus interesses em Educação Ambiental, datando-os em um momento histórico que se dá a partir de iniciativas de políticas públicas desenvolvidas na área ambiental pela Prefeitura Municipal de Pelotas, e, segundo eles, o maior impacto em seus interesses aconteceu com a criação e organização da SQA. Vejamos alguns depoimentos de professores ${ }^{3}$ que demonstram essa referência e as expectativas para com as ações dessa secretaria:

Busco apoio nos encontros, no material que a SQA tem. O Sanep, ${ }^{4}$ todos os anos, vem aqui, o pessoal do horto também. [...] A gente vê que de uns anos pra cá a SQA ajudou muito, é um suporte que a gente tem. (Professor José).

Eu aproveito tudo sobre o ambiental que encontro... Nas igrejas, na SQA, no Sanep, em tudo que puder, e quando tem algum evento e eu posso participar e acrescentar conhecimento naquilo que eu aprendi para repassar esse conhecimento, eu não perco tempo: eu gerencio a coisa na escola, negocio e vou. Hoje, com a SQA, a gente tem mais facilidade de encontrar coisas para trabalhar... Eles ajudam demais e estão sempre promovendo coisas, isso motiva e dá vontade de continuar... (Professora Ana).

Vou te dizer... Nós não temos muito conhecimento sobre o ambiental, não fomos formadas para isso. Eu tenho mais relação com a natureza porque fui criada no campo, vivi isso na minha vida, tenho uma relação de respeito e carinho com a natureza e depois me formei em Biologia, então isso tudo me dá mais condições. Mas falta muito para unir isso a EA. Antes, fazíamos tipo meio sem saber como, ia fazendo-se. O que não dá é para não fazer nada. Mas agora, com a SQA, eu acho que mudou um pouquinho... Pelo menos a gente tem apoio, referências e pode trazer alguém quando não se entende de alguma coisa... Isso, puxa, melhorou demais aqui para minha escola! Até outros professores começaram a se envolver, a perguntar... Essas coisas... (Professora Verônica).

${ }^{3}$ Os nomes dos professores são fictícios.

${ }^{4}$ Serviço Autônomo de Saneamento de Pelotas.

Para compreender essa relação, é preciso destacar que a criação da SQA foi algo muito representativo para o espaço ambiental municipal. O campo ambiental em Pelotas constituiu-se, desde os anos de 1980, 
como um espaço ativo de luta em torno da legislação ambiental local, preservação de áreas importantes para o equilíbrio ambiental (banhados, parques), construção de um Conselho de Proteção Ambiental com poderes deliberativos e tantas outras. Foi um campo que se formou pelo movimento de um conjunto de sujeitos envolvidos com os temas ambientais, geralmente ligados aos partidos de esquerda e influenciados por todo um movimento ambientalista que proliferava e pelo fortalecimento de algumas Organizações não Governamentais (ONGs). A partir de 2001, com a chegada do Partido dos Trabalhadores (PT) à administração municipal, foi criada a SQA, que passou a cuidar, exclusivamente, das questões ambientais. É importante destacar que o surgimento dessa secretaria não pode ser visto senão como produto de uma relação bastante ampla de alguns militantes de ONGs ambientalistas com o novo governo que se instaurava. Desde longos anos, eles reivindicavam um órgão como esse; a SQA, portanto, efetivou o sonho desses ambientalistas. A própria organização da secretaria e alguns cargos criados para seu funcionamento contaram com a participação de membros de ONGs pelotenses, inclusive o secretário e seus assessores, que eram reconhecidos ativistas do campo ambiental e oriundos, em sua maioria, de uma ONG tradicional no município. Essa ONG era fortemente relacionada com projetos e atividades ambientais desenvolvidas na cidade e mantinha uma relação de trabalho (projetos, oficinas, palestras, produção de material educativo) bastante vinculada a escolas e professores, não apenas de Pelotas, mas também de outros municípios próximos.

Com a estruturação da SQA, a prefeitura toma para si os compromissos e as decisões com os temas ambientais, e as políticas de gestão passaram a ser desenvolvidas a partir de quatro linhas básicas: controle e fiscalização ambiental; arborização da cidade; coleta seletiva do lixo; e Educação Ambiental. Desse modo, as escolas passaram a ser chamadas para se envolverem nos projetos e nas atividades realizadas e tornaram-se um espaço fundamental para a operacionalização e a intervenção de ações dessa secretaria. Entre as ações implementadas, algumas podem ser consideradas como carros-chefes, ou seja, como mecanismos importantes para atraírem as escolas e os professores, comprometendo-os com as iniciativas propostas pela SQA. No conjunto de ações que foram movimentadas, naquele momento, constava o projeto Recreando, ${ }^{5}$ que realizava oficinas de EA no Ecocamping municipal - área de preservação ambiental mantida pela prefeitura; a Oficina Ecopedagógica, que trabalhava com reaproveitamento de sucata e era oferecida exclusivamente a professores; o Projeto Adote uma Escola (Paue), que tratava de seletividade de resíduos. Esse último, por exemplo, era o projeto mais dinâmico entre a SQA e as escolas. Para participar do Paue, as escolas deveriam se ajustar a algumas condições estabelecidas pela secretaria: 1) ter projeto de EA; 2) ter um professor responsável pelo projeto; e 3) todos os professores da escola deveriam passar por um curso intitulado Oficina Ecopedagógica, no qual aprendiam a confeccionar brinquedos, jogos e enfeites a partir de materiais como papel, papelão, alumínio, plástico. Ao

\footnotetext{
${ }^{5}$ As atividades desse projeto aconteciam, geralmente, em comemoração à época da primavera. A SQA convidava mais ou menos cinco ou seis escolas e elas deviam selecionar dez alunos, principalmente, entre os de $4^{\mathrm{a}}$ e $5^{\mathrm{a}}$ séries. A SQA patrocinava ônibus para o deslocamento de estudantes e professores e organizava atividades em grupos que eram chamadas de oficinas ecológicas: trilha ecológica, oficina de sucata, plantios, pinturas com temas ambientais, sensibilização e jogos, futebol, fabricação de pandorgas, etc.
} 
fazerem parte do Paue, as escolas recebiam certo valor em dinheiro pelo recolhimento do lixo e, ainda, apoio técnico por parte da SQA (sacos de lixo, luvas, mudas, técnicos, palestras, etc.) para as atividades de Educação Ambiental que eram desenvolvidas. A SQA explica o funcionamento do projeto declarando que

alunos são motivados a trazer para a escola o lixo limpo de suas residências; os moradores do entorno da escola levam até a escola o seu lixo limpo; semanalmente, a prefeitura recolhe o lixo limpo que é levado para a unidade de triagem, onde é triado e prensado; o lixo limpo é comercializado pela indústria (pagam um valor maior que o intermediário); o resultado financeiro da venda do lixo limpo retorna para a escola que deverá aplicar a verba em EA. Em 2001, foram coletados em torno de 40 toneladas mensais, que iriam parar na natureza, e R\$ 16.000,00 distribuídos entre as escolas do projeto. A meta para 2004: atingir todas as escolas municipais e provocar adesão das estaduais, federais e particulares. (SQA. Guia do Sistema Municipal de Coleta Seletiva).

Os recursos que as escolas recebiam do Paue eram pequenos valores, mas faziam diferença, segundo os professores, diante das condições precárias em que elas se encontravam. Num primeiro momento, a verba era utilizada para as mais diferentes necessidades da escola - incrementar a merenda, comprar material de limpeza e fazer pequenos reparos - e, raras vezes, para atividades de Educação Ambiental. Vale a pena citar as palavras do professor José para ficar mais claro:

A escola utiliza este dinheiro para comprar coisas para o projeto, saídas com alunos e comprar materiais, e, muitas vezes, isso é vital... Se não tivesse esse recurso até ficaria difícil de fazer. Eu acho que foge dos objetivos da EA, mas é como eu te disse, lixo por lixo, mas se não tivesse esse recurso seria inviável alguma coisa, muitas vezes a gente quer fazer uma saída e não tem como solicitar verba e passagem. Não tem nem pra ônibus, pra gente sair e ir nos locais pra observar o meio ambiente, eu até acho contraditório estar sendo pago pra fazer o que deveria ser uma consciência ecológica, mas é uma contrapartida pra nós e é essencial. Se a prefeitura não pagar mais, a gente tem que continuar porque não dá mais pra parar. Até os pais cobram, mas é difícil. A gente tem até um projeto, agora, de comprar dois bebedouros... Não deixar o lixo esparramado por aí; é isso que a gente fala e vai reverter em benefício para os alunos. Então, desde o ano passado, a gente está guardando recurso pra comprar. Isso motiva e ajuda muito a escola que... Tu sabes as condições.

Além da concepção de uma Educação Ambiental centrada na natureza em si, observa-se que se perpetua, ainda, outra concepção: a econômica. Essa forma de relacionar a Educação Ambiental com trocas econômicas parece apontar para a ideia de que cuidar da natureza (limpá-la) pode ser lucrativo para quem o faz.

Além desses projetos, outras atividades desenvolvidas pela SQA e ofertadas ao público em geral contavam com intensa divulgação nas escolas e parceria com professores: Ecodebates, que contavam com palestras e discussões sobre temas ambientais, segundo a secretaria, 
polêmicos e pouco discutidos; ${ }^{6}$ o Junho Ecológico e a Semana da Primavera, eventos que aconteciam, respectivamente, em datas específicas como o dia mundial do meio ambiente (junho) e a chegada da primavera (setembro). A SQA produzia, também, materiais educativos impressos e digitais, que eram constantemente enviados às escolas ou procurados pelos professores para seus estudos e aulas e para organizarem eventos nas suas escolas ou na comunidade onde ela estava localizada. O Guia do Sistema Municipal de Coleta Seletiva (GCS), um livreto produzido pela SQA e que foi muito divulgado nas escolas, é outro bom exemplo dessa forte relação. Constituído pela descrição de projetos, dados sobre lixo, objetivos e importância da seletividade de resíduos e tipos de materiais a serem separados, tornou-se um subsídio muito solicitado e utilizado pelos professores nas escolas. Quero ressaltar que esses materiais eram de caráter prescritivo e comportamental: ditavam os modos e comportamentos tidos como, ambientalmente, corretos e que os sujeitos deveriam desenvolver e informavam as técnicas para plantar árvores ou para separar o lixo. Outro fator interessante é que alguns professores envolvidos com Educação Ambiental passaram, constantemente, a procurar os técnicos da SQA para participarem de suas atividades internas de formação de docentes ou educação dos alunos. O objetivo era que os membros da SQA oferecessem palestras, oficinas e outras atividades que tratassem de temas ambientais e que ajudassem esses professores a constituírem um espaço capaz de evidenciar a Educação Ambiental como algo importante para a comunidade escolar. Nessas condições, aos poucos, foi criando-se uma articulação intensa entre professores e a SQA.

Nesse movimento, a SQA ocupou função especial de poder, pois passou a ser reconhecida pelos professores como o segmento que detinha o poder de falar, produzir e gerir a verdade sobre o ambiente natural e as formas de tratá-lo. Ao assumir essa posição, a SQA colocou os professores em contato com seus panfletos, palestras, oficinas e projetos e os aproximou de discursos carregados de significados sobre as questões ambientais. Nesse caso particular, os objetivos da Educação Ambiental giravam em torno da gestão oficial ambiental, ou seja, de se produzirem políticas e ações técnicas para resolver os problemas enfrentados no ambiente: agressões aos elementos naturais, descumprimento da legislação, tratamento de água e esgoto, limpeza e manutenção de ruas e praças, despoluição da lagoa e outros. Essa forma técnica de tratar os temas ambientais produziu efeitos importantes nos modos de pensar e agir dos professores. Defendo que a relação que se instituiu entre a SQA e os docentes foi um fator que contribuiu, sobremaneira, para o fortalecimento de uma forma muito particular de fazer e pensar Educação Ambiental nas escolas. Nas condições em que o movimento se estabeleceu, as práticas priorizadas pelos professores foram centralizadas em ações pontuais, descontextualizadas e desarticuladas do currículo da escola. Esse tipo de compreensão da Educação Ambiental deu seguimento à reafirmação de um modelo de currículo que se assemelhava, no meu entendimento, ao que Santomé (1995) chamou de currículo turístico. Nos tópicos seguintes,
${ }^{6}$ Entre os temas escolhidos para essas atividades estavam: transgênicos, legislação ambiental, estações rádio-base, mudanças climáticas, água. 
discuto a ideia de currículo turístico e a aproximação que percebo com a Educação Ambiental e descrevo a produtividade desse currículo no interior das escolas e os significados de Educação Ambiental que nele prosperaram.

\section{Currículo turístico}

Por que currículo turístico?

Santomé (1995) denominou de currículo turístico aquele que teria as seguintes características principais: trivialização; superficialização e banalização dos temas; tendência a um estilo que se aproxima de algo como suvenires de uma viagem turística ou algo exótico; e que recebe tratamento em dias " $\mathrm{D}$ " (dias especiais) e funciona centralizado em ações que se caracterizam pela estereotipagem e pela utilização de estratégias que não levam em consideração os aspectos históricos que produziram certos problemas sociais, tomando, como ponto de partida, a análise do problema concreto, visível.

Com base nessas características, considerei que os currículos das escolas poderiam ser compreendidos a partir dessa imagem apresentada por Santomé, visto que as atividades e experiências de Educação Ambiental aconteciam em dias especiais e comemorativos - dia do Meio Ambiente, dia da árvore, dia da primavera, dia da água. Nesses dias, os alunos faziam exposições e gincanas em que, geralmente, competiam e ganhavam prêmios por recolherem garrafas $\mathrm{PET}^{7}$ embalagens, papel, vidros; apresentavam painéis com definições de flora e fauna ou sobre poluição da água, do solo e outras; realizavam visitas a áreas de preservação, que tinham como objetivo principal mostrar as belezas da natureza que pairava naquele local específico. Nessas atividades, alunos e professores costumavam estar munidos de uma parafernália de pacotes de biscoitos e batatinhas fritas e refrigerantes, que contribuíam, quase sempre, com uma série de embalagens jogadas como lixo por todas as partes do ambiente. Eram, também, comuns os mutirões para recolhimento de lixo que, por outro lado, buscavam mostrar os problemas apenas como aumento do desleixo em termos do destino final do lixo. Sobre os mutirões, que são atividades comuns a todas as escolas, os professores justificaram suas preocupações da seguinte maneira:

\footnotetext{
7 O Politereftalato de ETileno, desenvolvido por dois químicos britânicos Whinfield e Dickson em 1941, é formado pela reação entre o ácido tereftálico e o etileno glicol, originando um polímero, termoplástico. Utiliza-se principalmente na forma de fibras para tecelagem e de embalagens para bebidas.
}

[...] são comunidades muito pobres, alguns não têm noção de que essa sujeira pode afetar eles mesmos. É aí que entra a escola... Para trazer essa informação e fazer com que eles tenham ação, que entendam. (Professora Érica).

[...] ratos, baratas, junta tudo nesses lixos... Fica uma sujeira insuportável, imagina a natureza como fica com tudo isso. Imagina essas crianças, os nossos alunos... Muitos deles vivem em contato com tudo isso e eu fico pensando! A gente tenta falar, dizer e mostrar pra eles essas coisas. Dando o exemplo, também, com a separação do lixo, até mesmo na sala de aula... Agora, a gente tem duas lixeiras em todas as salas. (Professora Maria). 
Eu me lembro de um trabalho que eu fiz com a $4^{\text {a }}$ série. Um dia, o pátio estava muito sujo e eu perguntei o que a gente poderia fazer pra melhorar, e uma aluna disse: - Professora, vamos começar a juntar o lixo? Eu disse: - Boa ideia. Nós não tínhamos luvas e colocamos um saquinho plástico nas mãos. Juntamos uns dez sacos de lixo. Depois, para minha surpresa, eles começaram a cobrar dos colegas que colocavam lixo no chão. É isso, a gente conseguindo passar a ideia, isso se amplia para o resto da comunidade. (Professora Jéssica).

Eu trabalho na praça com os alunos, e a gente está sempre tirando o que está prejudicando. Como o trabalho é na praça, a gente está sempre exposto à chuva, à pedra, aos galhos que caem das árvores, ao lixo; então eu passo a mão no rastilho e vou limpando e digo pros alunos: - Vamos limpar, pessoal, e depois chamar o caminhão da prefeitura pra recolher. Tem que tirar, senão fica uma sujeira na praça e a natureza não é assim, né? E os alunos vão aprendendo... E a gente percebe que, nas salas de aula, não é mais tanta sujeira como era antes, eles colocam mais no lixo e, também, vêm mais limpinhos para a aula. (Professora Cátia).

A justificativa dos professores para esse tipo de ação educativa era que a escola e a comunidade estavam muito sujas devido à imensa quantidade de lixo acumulado em locais indevidos, como calçadas, terrenos baldios, esquinas, sacos de lixo rasgados, etc. Para resolver esses problemas, a escola teria a função de organizar atividades que conseguissem limpar todo aquele acúmulo de resíduos, considerando os problemas de enchentes, mas, principalmente, os de doenças e de estética, que eram verificados nesses locais. Assim, era comum que os professores organizassem, em determinados momentos, atividades nas quais os alunos recolhiam o lixo do pátio da escola ou de algum espaço na comunidade. Uma professora contou-me que, nos últimos tempos, essas atividades eram realizadas apenas com alunos de $5^{\mathrm{a}}$ e $6^{\mathrm{a}}$ séries, porque estava difícil sensibilizar os adolescentes de séries mais adiantadas. Segundo ela, os alunos mais velhos estavam muito mal-acostumados com as práticas de agressão ao ambiente e sentiam vergonha de ajudar a natureza nos mutirões de recolhimento do lixo.

Outra prática de Educação Ambiental muito utilizada pelos professores em algumas escolas que dispunham de espaços mais amplos era a de embelezamento do ambiente. Em horários alternativos, os docentes formavam grupos de alunos que se dedicavam à organização e ao cuidado de hortas e jardins. Em uma das escolas, tive a oportunidade de observar o início de uma atividade de construção de um jardim. Os alunos chegaram de chinelos, sem luvas, e, sem ao menos conversarem com o professor, dirigiram-se às pás que já estavam por ali e começaram a fazer buracos. Depois, o professor chegou e lhes mostrou como plantar as sementes. Ele logo se afastou - enquanto os alunos, sem muita habilidade com as pás, continuavam a bater no solo - dizendo-me que essa era uma prática da qual gostavam e seus pais também, porque eles não ficavam na rua sem fazer nada e aprendiam alguma coisa. Declarou-me que achava importante, porque os estudantes aprendiam a tratar com a natureza e a gostar dela, aprendiam como se faz para plantar, ao mesmo tempo que deixavam a escola com um aspecto mais bonito. O professor 
${ }^{8}$ De acordo com o professor, as mães reclamam muito que os filhos ficam em casa, por vezes sozinhos, sem terem o que fazer, e a tendência seria a de "seguirem más influências ou aprontarem bagunças".

9 Para estes professores, a EA deve ser realizada fora das salas de aula e os alunos devem ser colocados, sempre que possível, em contato com a natureza nas atividades e experiências que são propostas.

ainda salientou que as mães se envolviam na atividade: eventualmente, os alunos levavam mudas para suas casas e suas mães também mandavam outras. Nessa troca, para o professor, havia também uma aprendizagem das mães, que passaram a gostar mais das coisas da natureza. Nota-se que a Educação Ambiental pensada por esse professor tem características não só de moralizar as condutas dos alunos mediante práticas de manipulação do ambiente natural, mas também de entretê-los, colocá-los em atividades que os mantenham ocupados o maior tempo possível para que assim preencham seus momentos ociosos e não se voltem para comportamentos impróprios. ${ }^{8}$

Nas escolas desprovidas de espaços físicos para essas atividades, os professores lamentavam por não terem condições de realizarem tais experiências, ${ }^{9}$ como mostra, por exemplo, a fala da professora Jéssica:

Aqui não tem espaço para nada, isso é um grande problema para trabalhar o meio ambiente. Eu até pensei em deixar essa escola mais bonita e plantar umas florzinhas com os alunos pra eles terem um pouco dessa coisa de conhecer a natureza, mas tu vês!!! Como eu faço isso?

Assim como nas práticas de higienização do ambiente, nas de embelezamento o que contava era agir na natureza para modificá-la, curá-la de um mal que se apresentava ao olhar imediato, recuperar sua estética natural, deixá-la como a verdadeira natureza, ou seja, aquela que é simplesmente bela, limpa e ordenada pela ação do homem.

Quanto à organização curricular das áreas do conhecimento, a Educação Ambiental ocupava posição secundária em relação aos conhecimentos tradicionais, ou seja, ela acontecia quando o conteúdo, o horário ou a disponibilidade do professor permitia, como mostram os exemplos abaixo:

É bem difícil conciliar com os conteúdos porque tem a parte da gramática que a gente trabalha e... É... Muito importante, tu sabes, mas, quando dá, eu uso texto que fala da natureza, das árvores, dos animais. (Professora Érica).

Um grupo está fazendo trabalho com animais em extinção, o outro está trabalhando com música, mas eu nem sei o quê, porque tive que suspender e dar conta dos conteúdos que ficaram pra trás, senão a gente não vence tudo até o final do ano. (Professora Jéssica).

Eu faço o que é possível. Eu sei que, como professora, tenho que fazer, mas é quase nada, disso eu sei. A gente tem toda uma rotina de conteúdos que tem que vencer senão o aluno fica carente de alguma parte. Essa coisa de ambiente não está contemplada ali porque entendem que não é necessário, assim... Eu acho... Para o vestibular. Tem uma cobrança para o professor sobre o conteúdo que está nos planos da escola, se a gente não dá, até os pais cobram. Às vezes, eu faço planos: - Ah, vou fazer isso, vou trazer uns filmes, vou pedir uma pesquisa para sensibilizar... Mas aí, começa a apertar e a realidade me chama... (Professora Eliane).

É difícil colocar esse tema porque já tem tanta coisa que a gente precisa trabalhar durante o ano e, vou te dizer, às vezes a gente nem dá conta. Eu mesma tenho 40 horas e muitos alunos, aí, eu encaixo quando dá. 
Por exemplo, agora teve a feira de ciências e eu aproveitei para pedir que se fizesse alguma coisa sobre a natureza e surgiram coisas... Mas é assim, quando tem uma possibilidade. (Professora Rose).

É importante ressaltar que, nesse tipo de currículo que foi sendo construído nas escolas, os conhecimentos fundamentavam-se em significados naturalistas e pragmáticos (centrados na natureza em si), fragmentados, limitados e que obscureciam as relações históricas e políticas da construção e produção dos problemas ambientais. Problemas esses que derivam de um tipo de sociedade capitalista centrada na ampliação e na multiplicação de princípios de mercado e do consumo em todas as instâncias sociais e para a qual a natureza tem sempre a função de ser útil economicamente. Esse tipo de sociedade criou todo um sistema de razão (Popkewitz 1992, 1999, 2001, 2004; Popkewitz, Lindblad, 2004) - constituído de significados, conceitos, valores e sentidos para relações sociais, econômicas e políticas - que enreda a todos, e o ambiente natural tem uma posição e um papel que precisam ser pensados. A Educação Ambiental escolarizada, parece-me, não pode omitir esses fatos. Ao não considerar essas questões, pode acontecer que a Educação Ambiental, quando muito, consiga orientar seus estudantes para certos procedimentos prescritivos e comportamentais que, quase sempre, acabam com a própria atividade, como acontecia com as escolas estudadas. Nessas escolas, a consequência foi que os currículos de Educação Ambiental se associaram aos poucos, nessa dinâmica, especificamente à ideia de limpeza e embelezamento do ambiente e à ideia de que desse modo fosse possível conscientizar alunos e professores para uma forma mais responsável e reflexiva acerca da sua relação com as questões ambientais.

\section{Finalizando}

Neste artigo, tive a intenção de mostrar que os discursos sobre Educação Ambiental que aparecem no espaço escolar não são neutros ou naturais, mas que, ao se apresentarem como tais e com o objetivo específico de ajudar as escolas a desenvolverem a Educação Ambiental, quase sempre são aceitos sem serem questionados. Sendo simplesmente aceitos, como nas escolas estudadas, alguns discursos encontram um meio especial para conduzirem suas verdades. Esse foi o caso da relação entre os professores e os discursos da SQA, a qual foi bastante produtiva, pois marcou de forma especial as práticas de Educação Ambiental desenvolvidas nas escolas.

Num processo de composição em que os professores misturaram, amarraram, conjugaram suas ideias, práticas e conhecimentos com os discursos mobilizados pela SQA, um tipo de Educação Ambiental pôde ser pensado e fabricado. Isso demonstra que os discursos produzem (ou reafirmam) significados, verdades e representações que interferem em nossas ações e comportamentos. Assim, os guias, as cartilhas, as palestras, 
${ }^{10}$ Práticas ou modos de subjetivação compreendem o conjunto daquelas atividades, formas, técnicas e procedimentos calculados e planejados por meio dos quais os seres humanos são chamados a se transformarem e a se reconhecerem como sujeitos de (uma sexualidade, uma profissão, uma loucura, uma psiquiatria...), ou seja, é o conjunto das diferentes práticas de constituição de sujeito. as oficinas e as demais atividades oferecidas pela SQA às escolas podem ser consideradas estratégias discursivas que contribuíram para fazer transitar uma concepção de Educação Ambiental e seus significados no espaço da escola. Porém, mais do que isso, os discursos da Educação Ambiental funcionam como práticas discursivas de subjetivação, ${ }^{10}$ no sentido utilizado por Foucault (1990, 1988, 2006), que impõem verdades, regulam comportamentos e atitudes e, nesse sentido, constituem a interioridade das condutas. No entrecruzamento dessas práticas, configuram-se as formas pelas quais os sujeitos passam a se reconhecer como tendo condutas específicas. Portanto, são práticas que posicionam os alunos (e também os professores) em uma ordem de discurso que, com suas regras, normas, rituais e doutrinas, define quais características devem desenvolver aqueles que irão agir de forma ambientalmente correta, pressupondo, também, que aqueles que agem devem concordar com as verdades que são colocadas em ação. É nesse sentido que se manifesta a relação entre currículo e poder. O currículo, com as atividades de Educação Ambiental, define o que é necessário para os alunos se tornarem sujeitos mais conscientes, esclarecidos e responsáveis. Nas escolas investigadas, os professores priorizavam, como importante e verdadeiro para despertar essas condutas, a observação e a intervenção no ambiente natural. Nessas atividades, foram definidos um sentido e uma representação para a Educação Ambiental, limpeza e embelezamento do ambiente. Estavam definidos, também, os mecanismos que eles determinaram como sendo os que levariam os alunos a transformarem seus sentimentos e atitudes frente aos problemas ambientais: recolhimento e seletividade de lixo, passeio, observações, gincanas, plantios (de hortas e flores). Portanto, embora nessas atividades de Educação Ambiental pareça que não se ensinou nada, pois não foram utilizados livros, textos ou notas, nelas os alunos aprenderam muitas coisas. Nessas práticas, os professores ensinaram um determinado significado de Educação Ambiental, um significado para os comportamentos dos alunos e as posições que estes devem adotar frente aos problemas ambientais. Compreender a Educação Ambiental desse modo é considerá-la envolvida no governo das condutas, nos processos de subjetivação e na definição de certas práticas que conduzem os alunos a experiências de si mesmos, com outros e com o mundo. À medida que exerce esse tipo de poder, o discurso da Educação Ambiental escolar induz, favorece e estimula um modo de ser e agir para alunos e professores e, nessa relação, também exclui, impede, proíbe, limita outros caminhos e outras possibilidades.

Resumindo, o que está no centro deste texto é a questão do currículo e aquilo que ele faz e produz no espaço escolar. Quis chamar a atenção para o currículo como um artefato criativo que conduz poder e saber particulares e destaquei a participação política dos professores na seleção, na produção e no desenvolvimento dos currículos. Defendi que as escolhas, as opções e as decisões que alguns professores priorizam, também, criam e constroem condições para a escola, os alunos e os próprios professores. Acredito que pensar o currículo dessa forma é 
colocar em xeque a política curricular que queremos movimentar nas escolas: que significados culturais devem ser privilegiados, que vozes devem ser escutadas, como certas práticas devem ser implementadas, etc., sempre tendo em vista que o currículo é um lugar em que se produzem identidades, subjetividades, e, também, é um espaço onde convivem inclusão e exclusão.

\section{Referências bibliográficas}

BALL, S. Reformar escolas/reformar professores e os terrores da performatividade. Revista Portuguesa de Educação, Universidade do Minho, Braga, Portugal, v. 15, n. 2, p. 3-23, 2002. Disponível em: $<$ http://redalyc.uaemex.mx/pdf/374/37415201.pdf>. Acesso em: 8 mar. 2008.

BRASIL. Lei n 9.795, de 27 de abril de 1999. Dispõe sobre a Educação Ambiental, institui a Política Nacional de Educação Ambiental. Disponível em: <http://www.planalto.gov.br/ccivil_03/Leis/L9795.htm> Acesso em: 12 maio 2003.

CORAZZA, S. Que quer um currículo? Pesquisas pós-críticas em educação. Petrópolis, RJ: Vozes, 2001.

CORAZZA, S.; TADEU, T. Composições. Belo Horizonte: Autêntica, 2003.

COSTA, M. V. (Org.). O currículo nos limiares contemporâneos. Rio de Janeiro: DP \& A, 2003.

FISCHER, Rosa Maria Bueno. A análise do discurso: para além de palavras e coisas. Educação e Realidade, Porto Alegre, v. 20, n. 2, p. 18-37, jul./dez. 1995.

Foucault e a análise do discurso em educação. Cadernos de Pesquisa, São Paulo, n. 114, p. 197-223, nov. 2001.

FOUCAULT, M. O sujeito e o poder. In: DREYFUS, H.; RABINOW P. Michel Foucault, uma trajetória filosófica: para além do estruturalismo e da hermenêutica. Rio de Janeiro: Graal, 1990.

Microfísica do poder. Organizado por Roberto Machado.

Rio de Janeiro: Graal, 1988.

A arqueologia do saber. Rio de Janeiro: Forense Universitária,

2004. 
FOUCAULT, M. Historia da sexualidade I: a vontade de saber. Rio de Janeiro, Graal, 2006.

2008a. . Segurança, território, população. São Paulo: Martins Fortes, . Nascimento da biopolítica. São Paulo: Martins Fortes, 2008b.

GARCIA, M. M. O sujeito emancipado nas pedagogias críticas. Educação \& Realidade, Porto Alegre, v. 26, n. 2, p. 31-50, jul./dez. 2001.

LARROSA, J. Tecnologias do eu e educação. In: SILVA, Tomaz Tadeu da (Org.). O sujeito da educação: estudos foucaultianos. 5. ed. Petrópolis, RJ: Vozes, 2002.

MACHADO, Roberto. Introdução: por uma genealogia do poder. In: FOUCAULT, Michel. Microfísica do poder. Organizado por Roberto Machado. Rio de Janeiro: Graal, 1988.

POPKEWITZ, Thomas. Profissionalização e formação de professores: algumas notas sobre a sua história, ideologia e potência. In: NÓVOA, António. Os professores e a sua formação. Lisboa, Portugal: Dom Quixote, 1992.

. Reforma educacional e construtivismo. In: SILVA, Tomaz Tadeu da (Org.). Liberdades reguladas: a pedagogia construtivista e outras formas de governo do eu. Petrópolis, RJ: Vozes, 1999.

. Lutando em defesa da alma: a política do ensino e a construção do professor. Porto Alegre: Artmed, 2001.

- A reforma como administração social da criança: a globalização do conhecimento e do poder. In: BURBULES, N. et al. Globalização e educação: perspectivas críticas. Porto Alegre, Artmed, 2004.

POPKEWITZ, Thomas; LINDBLAD, Sverker. Historicizing the future: educational reform, systems of reason, and the making of children who are the future citizens. Journal of Educational Change, v. 5, n. 3, p. 229-247, 2004.

ROSE, Nikolas. Governing advanced liberal democracies. In: BARRY, A.; OSBORNE, T.; ROSE, N. (Ed.). Foucault and political reason: liberalism, neo-liberalism and rationalities of government. Chicago: The University Chicago Press, 1996.

SANTOMÉ, J. T. As culturas negadas e silenciadas no currículo. In: SILVA, Tomaz Tadeu da (Org.) Alienígenas na sala de aula: uma 
introdução aos estudos culturais em educação. Petrópolis, RJ: Vozes, 1995.

SILVA, Tomaz Tadeu da. Identidades terminais: as transformações na política da pedagogia e na pedagogia da política. Petrópolis, RJ: Vozes, 1996.

. Documentos de identidade: uma introdução às teorias do currículo. Belo Horizonte: Autêntica, 1999.

- O currículo como fetiche: a poética e a política do texto curricular. Belo Horizonte: Autêntica, 1999.

Mara Rejane Vieira Osório, é doutora em Educação pela Universidade Federal de Pelotas (UFPel), é professora do Departamento de Ensino da UFPel.

mareos@gmail.com

Recebido em 21 de novembro de 2010.

Aprovado em 25 de abril de 2011. 